Jurnal Konstruksi Hukum | ISSN: 2746-5055

Vol. 2, No. 3, September 2021 Hal. 645-649| Tersedia online di https://www.ejournal.warmadewa.ac.id/index.php/jukonhum

DOI:http://doi.org/10.22225/jkh.2.3.3672.645-649

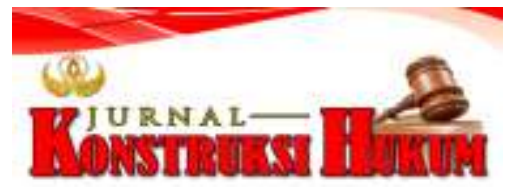

\title{
ANALISIS YURIDIS OMNIBUS LAW DALAM PENYUSUNAN RANCANGAN UNDANG-UNDANG CIPTA KERJA
}

\author{
I Kadek Semara Atmika, I Nyoman Budiartha \& Ida Ayu Putu Widiathi \\ Fakultas Hukum Universitas Warmadewa, Denpasar-Bali, Indonesia \\ semaraatmika2667@gmail.com, budiarthaputu59@gmail.com \& widiatidayu@gmail.com
}

\begin{abstract}
Abstrak
Negara Indonesia menganut Sistem Hukum Kontinental dengan banyak hukum dari benua ke provinsi. Oleh karena itu, banyak peraturan yang tumpang tindih secara vertikal dan horizontal. Rekonsiliasi diperlukan untuk mengelola regulasi yang tumpang tindih. Konsep hukum komprehensif berlaku baik di sebagian besar negara yang menganut sistem common law, namun Indonesia yang menganut sistem civil law masih asing dengan istilah tersebut. Oleh karena itu, pertanyaan yang diangkat dalam penelitian ini adalah: Satu. Tujuan penelitain adalah untuk mengkaji kedudukan hukum secara keseluruhan dalam berlakunya hukum Indonesia dan untuk membahas hukum komprehensifi berlaku untuk hukum penciptaan lapangan kerja. Survei ini adalah survei hukum, untuk itu penelitian ini menggunakan penelitian hukum normatif dengan menggunakan pendekatan perundang-undangan dan pendekatan konseptual. Hasil penelitian menunjukkan bahwa status dan penerapan hukum yang komprehensif sangat penting bagi pembangunan hukum yang meningkatkan kepastian hukum. Pembentukan undang-undang dengan konsep hukum yang komprehensif memerlukan penyelidikan yang luas, dan demi transparansi dalam proses perumusan, banyak partai politik berpartisipasi dan memastikan tidak menimbulkan masalah atau merugikan kepentingan umum, terutama kepentingan sosial.
\end{abstract}

Kata kunci: Omnibus Law, Peraturan Perundang-undangan, Cipta Kerja.

\begin{abstract}
Indonesia is a country that adheres to the civil law system, many regulations from central to regional. As a result, many laws and regulations overlap in both vertical and horizontal directions. To organize overlapping regulations, coordination must be done. The concept of comprehensive law has been successfully applied in most countries that adhere to the common law system, but Indonesia that adheres to the civil law systern is still unfamiliar with the term. Therefore, the goals of this research are to analyze the comprehensive legal position in the preparation of Indonesian law and to discuss comprehensive law applied in the law of job creation. This research is normative legal research, used statutory approach and conceptual approach. The results show that the status and application of comprehensive law is v'ery imponant for the development of the law to enforce legal certainty. The formulation of legislation with a comprehensive legal concept requires in-depth research, and for the sake of transparency in the formatinn of many political parties involved, so as nnt to cause problems and harm the public interest, especially the social interest.
\end{abstract}

Keywords: Omnibus Law, Legislation, work copyright.

\section{PENDAHULUAN}

Hukum merupakan cikal bakal pengaturan kehidupan suatu negara, dan merupakan instrumen hukum. Hal ini dianggap sebagai hal yang objektif, karena persiapan teknis berdasarkan prinsipprinsip hukum dari cabang legislatif dilakukan. Konsep negara hukum sebenarnya telah dikembangkan oleh para filosofis Yunani kuno. Mengakui prinsip-prinsip supremasi hukum, terutarna yang ditempatkan pada administrasi negara, dan menjunjung tinggi arnanat hukum. Dengan demikian, negara hukum dapat dipahami sebagai suatu konsep sebagai instrumen negara untuk mencapai tujuannya. Menurut Mochtar Kusumaatmadja, tujuan utama hukum adalah untuk menjamin ketertiban, definisi dan kepastian (Kusumaatmadja, 2002). Hukum dihadirkan dalam bentuk norma hukum, kumpulan dari berbagai bentuk hukum tertulis yang mengatur segala aspek 
kehidupan suatu negara atau masyarakat. Menurut Mahfud (2010), peraturan hukum adalah segala undang-undang dalam arti luas, yang dirumuskan secara khusus oleh pejabat yang berwenang dan disusun secara tertulis. Dengan perkembangan, prinsip-prinsip negara hukum dipengaruhi oleh kedaulatan rakyat dan penerimaan demokrasi. Aturan hukum dan kedaulatan rakyat terkait erat seperti dua sisi mata uang. Konsepsi negara hukum ini disebut democratische rechtsstaat. Hukum dirumuskan dan ditetapkan menurut prinsip-prinsip demokrasi. Demokrasi, di sisi lain, harus diatur oleh hukum atau tidak langsung dengan melingkari demokrasi pada prinsipnya. Melihat peraturan perundang-undangan sebagai pengejawantahan hukum sebagaimana enjelaskan bahwa salah satu unsur dari suatu undang-undang, disebut juga undangundang, bersifat umum dan mengikat secara tertulis (Bagir, 1992).

Kategori dan bentuk hukum bersifat hierarkis ini merupakan fenomena legislatif yang saat ini sedang mengemuka dan Controversial seizing dengan diajukannya Undang-Undang Penciptaan Lapangan Kerja (RUU) ke DPR. Perdebatan mengenai hal ini bukan tanpa alasan karena RUU tentang penciptaan lapangan kerja disusun oleh pemerintah. Kebijakan nasional mencakup banyak aspek. Karena salah satunya menyangkut bidang hukum, maka kebijakan yang menciptakan produk yang sah juga harus mendukung prinsip demokrasi. Sangat penting untuk memahami prinsip-prinsip regulasi. Memang ada acuan produk yang sah, dalam hal ini cara produksi yang legal yang memenuhi kebutuhan masyarakat saat itu. Jika asas tersebut tidak diikuti, salah satu asas tersebut terdiri dari peraturan-peraturan yang bersifat khusus yang didahulukan dari pada peraturan-peraturan umum, yang dapat menimbulkan banyak kesalahan dalam putusan pengadilan. Realitas hukum Indonesia masih jauh dari gambaran. Akibat tidak terintegrasinya aturan-aturan yang ada dan kualitas aturan-aturan tersebut yang tidak memadai, maka undang-undang yang harus memberikan kepastian hukum belum sepenuhnya dilaksanakan. Hal ini berdampak pada banyaknya mmpang tindih norma hukum pada tingkat yang sama dan pada tingkat desentralisasi yang berbeda. Ketika aturan duplikat menjadi tidak stabil secara hukum, masalah baru pasti muncul. Salah satunya adalah betapa sulitnya bagi pemerintah untuk menegakan atau menegakkan aturan hukum. Akibatnya, mjuan koordinasi atau tujuan undangundang tidak dapat diwujudkan atau dicapai. Oleh karena itu, diperlukan kemajuan hukum, termasuk omnibus law untuk mengatasi masalah ini.

Istilah bus law sempat ramai diperbincangkan dalam pidato pengukuhannya pada 20 Oktober 2019, dengan alasan bahwa konsep bus law merupakan solusi dari banyaknya regulasi di Indonesia yang menghambat jalannya pemerintahan. Ini adalah masalah utama mengingat ambiguitas aturan hukum dan investasi yang tumpang tindih, dan konsep omnibus law menarik perhatian sebagai solusi untuk masalah ini. Namun, karena undang-undang bus law merupakan konsep yang relatif baru di Indonesia, maka perlu memahami undang-undang dan peraturan yang berlaku agar dapat beroperasi secara efektif dan mencapai apa yang diharapkan RUU penciptaan lapangan kerja harus disebarluaskan sehingga setiap orang dapat menyampaikan pendapatnya sampai undang-undang yang menguntungkan diberlakukan. Terlepas dari kelebihan dan kekurangannya, pemerintah tetap mengesahkan UU Omnibus 2020 sebagai UU. Undang- undang ini merupakan terobosan untuk mengurangi tumpang tindih peraturan agar tidak menghambat kinerja pemerintah, dan harus menjadi konsep besar ke depan dalam proses legislasi.

Penelitian terdahulu yang relevan juga banyak yang memberikan bukti bahwa hal ini sangat penting untuk dibahas dan dikaji. Dalam penelitian Cakra \& Sulistyawan (2020) menjelaskan bahwa perlu adanya kompatibilitas penerapan konsep omnibus Law dalam sistem hukum Indonesia. Harmonisasi perundang-undangan sangat penting dilakukan untuk pembangunan hukum dan juga demi terealisasinya hukum yang multak dan pasti di Indonesia (Hayati, 2020). Dalam Penelitian Pitaloka (2021) meninjau Omnibus Law dengan menggunakan perspektif dari Undang-Undang Nomor 12 Tahun 2011 Tentang Pembentukan Peraturan Perundang-Undangan. Peneliti ingin membahas tentang kedudukan omnibus law dalam desain hukum di Indonesia dan bagaimana penetapan omnibus law dalam rancangan undang-undang hak cipta, untuk itu tujuan penelitian ini adalah untuk mengkaji kedudukan hukum secara keseluruhan dalam berlakunya hukum Indonesia dan untuk membahas hukum komprehensif berlaku untuk hukum penciptaan lapangan kerja. 


\section{METODE PENELITIAN}

Peneliti menggunakan jenis penelitian dan pendekatan hukum normatif dalam penelitian ini untuk menetapkan aturan dalam membangun sistem standar dalam cara penelitian. Penelitian ini merupakan penelitian yang berdasarkan pada perundang-undangan dan kesusastraan dan bersinggungan langsung dengan topik penelitian (Fajar \& Achmad, 2010). Apalagi bila asas-asas hukum yang mengatur peraturan hukum adalah doktrin, standar, dan aturan. Dengan menggunakan pendekatan Perundang-undangan dan pendekatan konseptual. Dalam penelitian ini digunakan bahan hukum primer dan sekunder sebagai bahan hukum. Peneliti memperoleh dokumen hukum yang diperlukan melalui studi catatan dan dokumen. Dokumen hukum yang terkait dengan masalah ini telah dikumpulkan. Dokumen hukum kemudian diproses melalui analisis analitis. Hukum untuk dapat menjawab pertanyaan-pertanyaan yang diperdebatkan.

\section{HASIL DAN PEMBAHASAN}

\section{Kedudukan Omnibus Law dalam Perancangan Undang-Undang di Indonesia}

Persyaratan formal untuk legalitas berlakunya hukum dan peraturan Indonesia harus sesuai dengan UU No. 12 Tahun 2011 untuk menghindari uji materil secara formal oleh Mahkamah Konstitusi pada 15 Mei 2019, ketika menjadi undang-undang. Praktik politik pada hakikatnya harus didasarkan pada legitimasi rakyat atau legitimasi demokrasi. Artinya, semua kebijakan dan pembangunan legislatif harus memenuhi tujuan undang-undang yaitu memiliki tiga undangundang dasar. Gagasan yang diidentifikasi oleh sebagian besar ahli teori dan filsafat hukum adalah tiga tujuan hukum, antara lain keadilan, kemudahan, dan kepastian hukum (Poerwadarminta, 1986). Dan baru-baru ini pemerintah mengusulkan kepada DPR RI RUU penciptaan lapangan kerja. Asas hukum dapat menjadi dasar untuk mengembangkan norma hukum yang berkaitan dengan penegakan peraturan hukum dan dapat dijadikan acuan atas dasar landasan atau tujuan hukum Administrasi Terkait (Budiartha, 2016). Jika undang-undang penciptaan lapangan kerja yang komprehensif disahkan, itu dapat membingungkan, bukan hanya karena tidak mendukung daerah, tetapi juga karena dapat menyebabkan kebingungan jika diberlakukan. Padahal UU Cipta Kerja Komprehensif diharapkan dapat menggantikan ketentuan yang tumpang tindih yakni 82 undang-undang menjadi undang-undang tunggal. Tetapi sebaliknya, duplikasi telah meningkat sebelumnya, karena undang-undang. Ada beberapa undang-undang, beberapa di antaranya belum sepenuhnya dihapuskan. Jadi, meskipun tidak ada cara untuk menyederhanakannya, menggunakan "hukum global" ini akan semakin membingungkan masyarakat umum, pelaku bisnis, dan lembaga penegak hukum. Ketika "Hukum Komprehensif" menjadi undang-undang, tidak akan berfungsi secara efektif pada tahap penegakan karena ketentuan penegakan diperlukan untuk penegakan "UU Pemberlakuan Hukum yang Komprehensif". Setelah RRU itu disahkan, sekitar 519 aturan pemerintah, 14 aturan presiden, dan satu aturan kementerian akan diberlakukan. Untuk meringkas seluruh ketentuan penegakan hukum hak cipta, 534 ketentuan penegakan hukum perlu diterbitkan, yang kemungkinan besar tidak akan selesai satu atau dua tahun sebelum masa jabatan Jokowi berakhir. Salah satu penyebab banyaknya undang-undang yang sekarang tidak berlaku dan mubazir adalah karena undang-undang tersebut telah dihapus dan diganti dengan yang baru, tetapi aturan pelaksanaan undang-undang tersebut belum terbentuk.

\section{Penerapan Omnibus Law dalam Undang-Undang Cipta Kerja}

Alasan obyektif mengapa pemerintah mengadopsi konsep ini bukan hanya karena kontradiksi dalam standar hukum yang mendasari pengembangan omnibus law, tetapi juga aspek teoritis, filosofis dan hukum yang harus dipertahankan oleh pemerintah. Salah satu upaya utama yang dapat dilakukan pemerintah saat ini adalah mensistematisasikan konten atau sifat konten hukum yang saling bertentangan. Teori perundang-undangan dikonstruksi menurut teori perundangundangan, dan urutan pembentukannya dikaitkan dengan hukum perundang- undangan (Atmadja \& Budiartha, 2018). Hukum harus melibatkan orang, begitu pula saat membuat aturan dengan konsep omnibus law. Menurut Vivitri Susanti, ada perbedaan antara partisipasi dan sosialisasi. 
Partisipasi adalah untuk mencapai aspirasi, untuk mempromosikan informasi tentang perkembangan hukum, dan sosialisasi untuk mempresentasikan proyek-proyek yang ada. Omnibus law memiliki karakteristik khusus yang dapat merugikan demokrasi. Penetapan konsep ini dapat menembus banyak pemangku kepentingan, sehingga DPR dan pemerintah perlu memperluas akses informasi dan melibatkan seluruh masyarakat. Jika mengacu pada UndangUndang Nomor 12 Tahun 2011, ketentuan Pasal 96 Undang-Undang Nomor 12 Tahun 2011 juga dilaksanakan secara formal. Dalam hal ini, negara harus membuat saluran untuk mengkomunikasikan secara jelas wadah yang akan dipegang dan keterlibatan masyarakat. Hingga saat ini mekanisme partisipasi masyarakat masih belum jelas, sehingga partisipasi masyarakat hanya dianggap sebagai persyaratan resmi undang-undang. Massa rakyat adalah badan utama hukum dan harus berpartisipasi di dalamnya. Untuk mempersiapkan legislasi, masyarakat terlebih dahulu harus ikut menentukan arah kebijakan.

Peraturan hukum tidak dapat diatur dan dilaksanakan dengan baik tanpa partisipasi masyarakat. Memang, salah satu persyaratan utama untuk menghasilkan umpan balik adalah partisipasi dalam masyarakat. Menurut Nonet dan Selznick, pentingnya partisipasi masyarakat dalam pembentukan produk hukum adalah membentuk partisipasi dengan melibatkan sebanyak mungkin partisipasi semua sektor masyarakat dari sudut pandang individu dan kelompok masyarakat. Anda juga harus memulai dengan keinginan dan harapan masyarakat dan aspirasi. Sayangnya, hukum telah melupakan hak setiap orang untuk mendapatkan kesempatan yang sama. Keterlibatan masyarakat tidak memiliki jaminan hukum yang lebih baik, khususnya untuk mekanisme pemantauan aspirasi masyarakat dan pernantauan aspirasi tersebut, dan untuk pengembangan mekanisme komunikasi atau aspirasi dua arah. Masyarakat sering dilupakan dalam proses legislasi dan karenanya menolak hukum di masyarakat. Kurangnya partisipasi publik memberi RUU itu hak veto yang luas, dan bahkan amandemen yang tidak berdasar harus ditinjau konstitusional oleh Mahkamah Konstitusi. N arnun karena keberanian dan likuiditas partisipasi rnasyarakat tidak diketahui, maka partisipasi masyarakat dalam peraturan perundangundangan hanya dapat dijadikan sebagai syarat formal yang tidak baku. Tidak adanya platform dan proses yang jelas juga menimbulkan klaim bahwa partisipasi publik hanyalah hasil operasi. Begitu kehendak publik terbentuk, pengingkaran hukum tidak benar-benar terjadi. Jika kebijakan itu tidak diinginkan, kriteria yang menentukan siapa mendapat apa bisa dipertanyakan. Di sisi lain, proses pembuatan kebijakan yang terbuka dan akrab tampaknya tersembunyi. Demikian pula, konsep omnibus law diterapkan untuk memenuhi keinginan pemerintah untuk mengubah dan/atau mencabut banyak undang-undang yang diyakini menghambat perekonomian dan investasi, hasilnya adalah produk yang sah. Undang-Undang Komprehensif tentang penciptaan lapangan kerja di harapkan dapat mengubah ketentuan yang tumpang tindih dari 82 undangundang menjadi satu undang-undang dan mempromosikan investasi di Indonesia. Di sisi lain, peraturan telah berubah dan hanya beberapa peraturan yang dihapus dari undang-undang yang lama. Meningkatnya duplikasi dengan peraturan perundang-undangan yang belum sepenuhnya menghapuskan undang-undang tersebut, seluruh pasal dalam pasal ini dan setiap klausa pasal tersebut adalah 1.028 halaman. Jadi sementara tidak ada cara untuk menyederhanakan ini, menggunakan omnibus law akan semakin membingungkan bisnis populer dan pejabat penegak hukum. Hukum Komprehensif Undang- undang ini tidak akan berjalan efektif pada tahap penegakan. Sebab, ketentuan harus ditetapkan agar UU Ketenagakerjaan Komprehensif dapat berlaku. ltu sebabnya SK yang bersumber dari omnibus law tidak jelas. RUU harus dianggap sebagai undang-undang baru, tetapi jika dokumen tentang undang-undang yang diubah diterbitkan, teknik pembentukannya tidak tunduk pada lampiran undang-undang yang membuat undang-undang tersebut.

\section{SIMPULAN DAN SARAN}

\section{Simpulan}

Dari penjelasan diatas dapat disimpulkan bahwa UU Cipta kerja diharapkan mampu mengikat ambiguitas dan undang-undang yang tumpeng tindih dalam peraturan hukum di Indonesia. Legislasi yang komprehensif bukanlah cara untuk mengatasi masalah regulasi yang tumpang 
tindih dengan mencabut banyak peraturan dan mengubah suara Proposisi 82 menjadi undangundang penciptaan lapangan kerja atau undang-undang tunggal. Perselisihan muncul ketika hukum mulai berlaku. Omnibus law memiliki gaya sendiri yang dapat merugikan pihak-pihak tertentu, dan merusak demokrasi Indonesia bila tidak tepat sasaran. Olehkarenya, dalam penetapan konsepnya kelibatan masyarakat sangatlah dibutuhkan. Dalam hal ini, negara harus membuat saluran untuk mengkomunikasikan secara jelas wadah yang akan dipegang dan keterlibatan masyarakat. Hingga saat ini mekanisme partisipasi masyarakat masih belum jelas, sehingga partisipasi masyarakat hanya dianggap sebagai persyaratan resmi undang-undang. Massa rakyat adalah badan utama hukum dan harus berpartisipasi di dalamnya. Untuk mempersiapkan legislasi, masyarakat terlebih dahulu harus ikut menentukan arah kebijakan.

\section{Saran}

Melalui kajian ini peneliti ingin menyampaikan beberapa saran yang kiranya dapat memberikan sumbangsi pemikiran yang dapat membantu dalam penetapan konsep dan penyebaran informasi. Presiden akan segera menerbitkan Keputusan Presiden terkait lembaga yang dipimpin oleh Kepala Badan Mgislati f yang menangani pekerjaan administrasi di bidang peraturan perundangundangan, yang dikodifikasikan dengan Undang- Undang Nomor 15 Tahun 2019 (Perubahan Undang- Undang Nomor 12 Tahun 2019). Salah satu fungsi surat undangan adalah untuk menangani duplikat aturan menggunakan undang-undang lengkap berdasarkan UU No. 12 Tahun 2011. Dan Pemerintah harus segera menyiapkan regulasi untuk penegakan hukum umum tentang penciptaan lapangan kerja. Pemerintah juga perlu memantau kebijakan pemerintah, khususnya yang terkait dengan regulasi, sebagaimana diatur dalam undang-undang ini agar pemberlakuan undang-undang ini dapat memberikan dampak positif bagi perekonomian nasional di masa mendatang. Masyarakat harus lebih sadar akan hak-haknya dalam politik dan membuat ketentuan hukum agar tidak ada lagi wilayah kekuasaan birokrasi dan parlementer.

\section{DAFTAR BACAAN}

Atmadja, I. D. G., \& Budiartha, I. N. P. (2018). Teori-Teori Hukum. PT. Citra Intrans Selaras, Malang.

Bagir, M. (1992). Dasar-Dasar Perundang-Undangan Indonesia. Ind-Hil, Jakartra.

Budiartha, I. N. P. (2016). Hukum Outsourcing: Konsep Alih Daya Bentuk Perlindungan dan Kepastian Hukum. Setara Press, Jakarta.

Cakra, I. P. E., \& Sulistyawan, A. Y. (2020). Kompabilitas Penerapan Konsep Omnibus Law dalam Sistem Hukum Indonesia. Jurnal Mengenai Dasar-Dasar Pemikiran Hukum: Filsafat Dan Ilmu Hukum, Vol.2(2).

Fajar, M., \& Achmad, Y. (2010). Dualisme penelitian hukum: normatif \& empiris. Pustaka Belajar. Yogyakarta.

Hayati, N. N. S. (2020). Analisis yuridis konsep Omnibus Law dalam harmonisasi peraturan PerundangUndangan di Indonesia [Pasca Sarjana. Universitas Islam Negeri Sunan Ampe Surabayal].

Kusumaatmadja, M. (2002). Konsep - Konsep Hukum Dalam Pembangunan. Alumni. Bandung.

Mahfud, M. (2010). Konstitusi dan Hukum dalam Kontroversi Isu. Rajawali Pers, Jakarta.

Pitaloka, C. A. (2021). Kajian Yuridis Penerapan Metode Omnibus Law dalam Perspektif Undang-Undang Nomor 12 Tahun 2011 Tentang Pembentukan Peraturan Perundang-Undangan. Fakultas Hukum. Universitas Muhammadiyah Jember.

Poerwadarminta, W. J. S. (1986). Kamus Umum Bahasa Indonesia. Balai Pustaka, Jakarta. 